\title{
THE COUNCIL OF BRITISH OPHTHALMOLOGISTS, ITS CONSTITUTION, AIMS AND WORK
}

The following brief account of the formation and activities of the Council is published to make more widely known its constitution, the purposes for which it was founded, and the work it has accomplished.

THE Council of British Ophthalmologists was founded at a meeting held at the House of the Royal Society of Medicine on May 2, 1918. It owed its inception to the need for some body which could act authoritatively in regard to any questions of ophthalmological interest arising in connection with national industries or public services. Formerly such questions were referred, either to scientific societies, which were not constituted to deal with them, or to individual ophthalmic surgeons, who could express only their own opinions. Fortunately, many of those surgeons to whom application was made were well fitted to give advice, but some at least felt that advice would be of more value if given after the subject had been considered by a council representative of the general body of British ophthalmologists.

The following are the rules of the Council :

1. Name. The Council shall be called "The Council of British Ophthalmologists."

2. The functions of the Council shall be to take cognizance of and act in all matters of ophthalmic interest arising in connection with national industries and public services, and to initiate or advise concerning movements which have for their objects the welfare of the eyesight of the community.

3 . The Council shall consist of $(a)$ the Presidents and Past Presidents of the Ophthalmological Society of the United Kingdom and of the Section of Ophthalmology of the Royal Society of Medicine and the Master of the Oxford Ophthalmological Congress; $(b)$ ten members elected annually, four by the Council of the Ophthalmological Society, four by the Council of the Section of Ophthalmology of the Royal Society of Medicine, and two by the Council of the Oxford Ophthalmological Congress. The elected members shall commence their duties on July 1 in each year.

The Council shall have power to co-opt any individual to act with it for any special purpose and may delegate similar powers to any committee.

4. The Officers shall consist of a President, two Vice-Presidents, a Secretary, and a Treasurer, to be elected annually.

5 . The Council shall meet at least once in every quarter. Five shall form a quorum. 
6. An Executive Committee shall be appointed consisting of the President and Secretary, ex officiis, and four other members of the Council elected annually. It may be called together by any one of its members to consider urgent business. Three shall form a quorum.

7. The expenses of the Council shall be met by a guarantee fund and by voluntary contributions. The amount called up in any one year shall be proportioned to the amount guaranteed.

A meeting open to all British Ophthalmologists is held once a year, usually at the time of the annual congress of the Ophthalmological Society of the United Kingdom. The annual report of the Council is presented to this meeting and is subsequently published in the British Journal of Ophthalmology.

The Council has appointed numerous committees to investigate and report upon questions engaging its attention. The power of co-option authorized by Rule 3 has frequently been exercised. Ophthalmologists who are not members of the Council, and representatives of other branches of science, e.g., physiologists; physicists and illuminating engineers, have served on committees when their special knowledge has been thought necessary for the elucidation of the subjects under consideration. Co-opted members are invited to attend the meetings of the Council at which the reports. of the committees on which they serve are considered.

All reports passed by the Council for publication appear in the BRITISH JOURNAL OF OPHTHALMOLOGY, and those of more general interest have also been published in other medical periodicals and in the lay press.

The following is a list of the published reports :

${ }^{*}$ On Standard Illumination of Snellen's Distant Test Types (Brit. Jl. of Ophthal., Vol. III, p. 22, 1919).

*On the Teaching and Examination of Medical Students in Ophthalmology (Brit. Jl. of Ophthal., Vol. III, p. 165, 1919).

* On the Desirability of a Special Qualification in Ophthalmology (Brit. Jl. of Ophthal., Vol. III, p. 558, 1919).

On the Visual Requirements of Persons Licensed to Drive Mechanically-Propelled Vehicles on Public Roads (Brit. Jl. of Ophthal., Vol. IV, p. 28, 1920).

${ }^{*}$ On the Standardization of the Notation of the Axes of Cylinders (Brit. Jl. of Ophthal., Vol. V, p. 317, 1921).

* On the Institutional Treatment of London County Council School Children Suffering from Contagious Eye Diseases (Brit. Jl. of Ophthal., Vol. V, p. 280, 1921).

"Copies of these reports may be purchased from the Hon Secretary, W. H. McMullen, 86, Brook Street, Grosvenor Square, London, W.1 
*On some Public Authorities who are in the Habit of Referring Ophthalmic Cases to Hospitals for Examination and Treatment and (or) Report (Brit. Jl. of Ophthal., Vol. V, p. 467, 1921).

*On Sight-Testing by Opticians (Brit. Jl. of Ophthal., Vol. VI, p. 554, 1922).

*On Standards of Vision for Candidates for Scholarships and Teacherships under Local Education Authorities (Brit. $\mathrm{Jl}$. of Ophthal., Vol. VIII, p. 167, 1924).

*On the Institutional Treatment of Keratitis (Brit. Jl. of Ophthal., Vol. VIII, p. 233, 1924).

On the Administration of Optical Benefit by Approved Societies (Brit. Jl. of Ophthal., Vol. VIII, p. 61, 1924).

The Council has sent its reports to the various public authorities concerned, and has communicated with them by letters, by personal interviews with representatives, and by deputations.

The advice of the Council has been sought by various public bodies, and representatives were nominated to serve on a joint committee of the London County Council, and the Illuminating Engineering Society on Eye-Strain in Cinemas (Report in Brit. Jl. of Ophthal., Vol. IV, p. 482, 1920), and on a joint committee of the Illuminating Engineering Society and other bodies on Glare from Motor Car Headlights.

Representations have been made repeatedly to the General Medical Council urging that ophthalmology should be made an obligatory subject in all qualifying examinations, but hitherto without success. That Council has, however, recommended : "That every student should be required to attend a course of practical instruction in ophthalmology of not less than ten weeks' duration, and that no student should be admitted to the final examination unless he presents a certificate to the effect that he has attended such a course regularly and that his work in connection therewith has reached a satisfactory standard."

The report on the visual requirements of motor drivers was communicated to the police authorities in London and elsewhere. Some improvement in the standards required has followed.

As the result of a deputation of the Council to the Ministry of Health, institutional treatment for contagious eye diseases has been made available for London County Council school children; and in accordance with the recommendations in the report on institutional treatment of keratitis the Ministry has issued an instrument enabling the Metropolitan Asylums Board to undertake treatment of children suffering from interstitial keratitis.

The standards of vision recommended for candidates for scholarships and teacherships under Local Education Authorities have been adopted by the Board of Education, and the Council's

\footnotetext{
*Copies of these reports may be purchased from the Hon. Secretary, W. H. McMullen, 86, Brook Street, Grosvenor Square, London, W.1.
} 
report on the subject was published in the official journal of the department.

The question of the provision of optical or ophthalmic benefit for insured persons under the National Health Insurance Acts has received the close attention of the Council. An interim report on the subject was published in February, 1924 (Brit. Jl. of Ophthal., Vol. VII, p. 61). In April, 1924, a deputation proceeded to the Ministry of Health to discuss the subject. In May, 1924, a meeting of the Council and representatives of the British Medical Association was held, when it was agreed that a joint committee of the two bodies should be formed in order to co-ordinate their actions in regard to this subject. This committee drew up a series of recommendations, which were approved by the Council, forwarded to the Ministry of Health, and published in the BrITISH Journal of Ophthalmology (Vol. VIII, p. 590, 1924).

At the present time committees are dealing with the following subjects : (1) Standardization of test-types; (2) the methods adopted in various parts of the British Isles for the education of children suffering from defective eye-sight due to myopia and other causes; (3) the extent to which effect has been given to the recommendation of the Departmental Committee on the Causes and Prevention of Blindness in respect of industrial eye diseases and accidents.

The endeavour to protect the public from injury by untrained and incompetent persons professing themselves capable of treating. defects of the eyes calls for the constant vigilance of the Council.

The above epitome of the Council's activities will suffice to show that it has justified its existence and effectively served the purposes for which it was founded. It appears probable that with increasing recognition by various public bodies its usefulness will steadily become greater.

\section{OPHTHALMIC BENEFITS FOR MEMBERS OF APPROVED SOCIETIES}

Our readers will be interested to know the state of affairs with regard to the administration of ophthalmic benefits for members of approved societies. We, therefore, quote in full the admirable résumé published in the Lancet for January 3 of this year:

"One of the subjects before the Royal Commission on National Health Insurance now sitting is the best way to dispose of the surpluses which some of the approved societies possess and which are available for the granting of certain additional benefits to their members. There are 18 of these 'additional benefits,' and according to an official statement prepared for the use of the Commission and already published as a Blue-book* the most 
popular of the additional benefits, next to dental treatment, is the so-called 'optical benefit.' For the year 1924 nearly $£ 40,000$ is available for it. In one very large society, already, the claims have numbered 500 a week. A 'model schedule' provides that 'payment in respect of the cost of an optical appliance shall only be made on the production of a prescription from a qualified practitioner or a hospital.' In some instances, says the statement, and in particular in rural districts, it has been found that to insist on this condition is impracticable and its strict enforcement has been relaxed. If we may believe a writer in the Optician, as a matter of fact, all the largest approved societies (and many of the smaller ones) send their members to an optician, and not to a qualified practitioner or a hospital. Whether or not this statement of the case requires qualification, there is, at any rate, sufficient truth in it to demand the attention of those medical bodies whose duty it is to have regard both to the professional interests of their members and to the preservation of the nation's eyesight. Three such bodies exist and are at present jointly concerned in considering the various problems under review with the object of ensuring that the model schedule of the Ministry of Health, just quoted, which at present, unfortunately, is in danger of becoming a dead-letter, may become really effective. The first of these three bodies is the Council of British Ophthalmologists, formed in 1918, representative of the Ophthalmological Society and the Ophthalmological Section of the Royal Society of Medicinet; the second is the Ophthalmic Committee of the British Medical Association, and the third is the 'Ophthalmic Benefit Committee,' which has been formed during the past year, membership of which is open to those who hold or have held posts as surgeons, assistant surgeons, clinical, or refraction assistants at the ophthalmic hospitals or general hospitals with ophthalmic departments, and are in regular ophthalmic practice. The chairman of this Committee is $\mathrm{Mr}$. H. L. Eason, senior ophthalmic surgeon to Guy's Hospital. It is understood that the aims of these three bodies with regard to the matter at issue are in perfect harmony.

Last spring a joint committee was formed by the first two bodies, which drafted a scheme for ophthalmic benefit, and this committee has now agreed to allow equal representation to the Ophthalmic Benefit Committee in any approach to the Ministry of Health and in considering the various problems under review. It is

\footnotetext{
* Appendix to Minutes of Evidence, Part I. Statements prepared by certain Government Departments. H.M. Stationery Office. 8s. Ed.

† As our readers are aware the Council of British Ophthalmologists is even more representative of British Ophthalmology than here indicated. [EDITOR-Brit.Jl. of Ophthal.]
} 
proposed that a list of ophthalmic medical practitioners qualified and willing to see insured members of approved societies should be prepared in accordance with the following principles. Anyone desiring to join in the scheme will have to furnish evidence $(a)$ that he has held hospital or other appointments affording special opportunities for acquiring special skill and experience of the kind required for the performance of the service rendered, and has had actual recent practice in performing the service rendered or services of a similar character; or (b) that he has had special academic or post-graduate study of a subject which comprises the service, rendered, and has had actual recent practice as aforesaid; or $(c)$ that he is generally recognized by other practitioners in the area as having special proficiency and experience in a subject which comprises the service rendered."

\section{ANNOTATIONS}

\section{Cranial Artefacts}

In an article (Rev. gén. d'Ophtal., March, 1924), dealing with a case of oxycephaly, Cosmettatos, of Athens, makes a remarkable statement of a custom in Greece which is probably unknown to the majority of readers of this journal. The paragraph is the following : "The history and the typical symptomatology of our patient exclude the hypothesis that the abnormal form of the skull is to be attributed to an artificially brought about deformity. This custom is fairly wide-spread in Greece and especially in Epirus, the custom, namely, of exerting pressure upon the occiput of new-born children so as to produce flattening of the occipital region of the skull." De gustibus non est disputandum. The Chinese, in the past, were accustomed to squeeze the feet of their infants; the modern Greek apparently squeezes the other end of the baby. The Armenians are in the habit of putting a dry cloth round the infant's head and afterwards damping it in order to produce the typical sloping forehead which is characteristic of so many of this race. The shape of the skulls depicted on ancient Hittite monuments shows similar characteristics, and may have been produced in the same way, since the Armenians are usually regarded as descended from this race.

\section{Refraction in General Practice}

In the British Medical Journal for December 6, 1924, is an article by Dr. MacRae, of Corbridge-on-Tyne, on this subject ; and a very good article it is.

As soon as anyone is qualified there is nothing to stop him or her from setting up as an oculist. There is no reason why any who 